\title{
Study on Modification of NaX Zeolites: The Cobalt (II)-Exchange Kinetics and Surface Property Changes under Thermal Treatment
}

\author{
Hoai-Lam Tran, ${ }^{1,2}$ Maw-Suey Kuo, ${ }^{3}$ Wein-Duo Yang, ${ }^{1}$ and Yu-Chang Huang ${ }^{1}$ \\ ${ }^{1}$ Department of Chemical and Materials Engineering, National Kaohsiung University of Applied Sciences, \\ 415 Jiangong Road, Kaohsiung 807, Taiwan \\ ${ }^{2}$ Faculty of Chemistry, Dong Thap University, Dong Thap 93000, Vietnam \\ ${ }^{3}$ Forever Applied Equipment Co., Ltd., 3 Gongwu Road, Longtan Township, Taoyuan 325, Taiwan
}

Correspondence should be addressed to Wein-Duo Yang; ywd@kuas.edu.tw

Received 31 December 2015; Accepted 7 March 2016

Academic Editor: Barbara Gawdzik

Copyright (C) 2016 Hoai-Lam Tran et al. This is an open access article distributed under the Creative Commons Attribution License, which permits unrestricted use, distribution, and reproduction in any medium, provided the original work is properly cited.

\begin{abstract}
The cobalt (II) ion-exchange process followed the Freundlich and Langmuir adsorption models as well as the pseudo-secondorder kinetic model. The cobalt-exchanged contents increased when the initial $\mathrm{Co}\left(\mathrm{NO}_{3}\right)_{2}$ solution concentration increased up to $0.14 \mathrm{~mol} \mathrm{~L}^{-1}$ at the optimal $\mathrm{pH}$ of 6.05 . The $\mathrm{N}_{2}$ adsorption isotherms are mixed types $\mathrm{I} / \mathrm{II}$ isotherms and $\mathrm{H} 3$ type hysteresis. Both the micropore and mesopore adsorptions occurred during the adsorption process. The modification, which is both the cobalt (II) exchange and thermal treatment, significantly improved the surface properties of NaX zeolites. Accordingly, the optimal temperature range is 500 to $600^{\circ} \mathrm{C}$ for a thermal treatment. This is consistent with the results of XRD analysis.
\end{abstract}

\section{Introduction}

$\mathrm{NaX}$ zeolites are a synthetic zeolite that have been used and studied as ion exchanger, sorbents, and catalysts in chemical industrial processes [1] due to their large void volume of $50 \%$ of the frame structure. NaX zeolites structure is a faujasite framework with a cage comprising $\mathrm{SiO}_{4}$ and $\mathrm{AlO}_{4}$ tetrahedra bound by bridged oxygen atoms to make a 12ring pore openings and 3-dimensional channel system. The negative charges of the $\mathrm{AlO}_{4}$ units are balanced by sodium cations that can be easily exchanged by other metal ions such as $\mathrm{Ni}^{2+}, \mathrm{Cr}^{3+}, \mathrm{Zn}^{2+}, \mathrm{Cu}^{2+}$, and $\mathrm{Co}^{2+}$ ions [2-5]. This exchange capacity of $\mathrm{NaX}$ zeolites makes them very efficient adsorbents or catalysts due to the zeolite framework destruction. Additionally, the $\mathrm{NaX}$ zeolites are the most common commercial adsorbent. Therefore, the $\mathrm{NaX}$ zeolites were used for modification in this work by the cobalt (II)-exchange process.

By using single-crystal X-ray diffraction, Olson determined the locations of $\mathrm{Na}$ ions in dehydrated $\mathrm{NaX}$ zeolite
$\left[\mathrm{Na}_{88} \mathrm{Al}_{88} \mathrm{Si}_{104} \mathrm{O}_{384}, F d 3, a_{0}=25.009(5) \AA\right]$. In each unit cell, the occupancy of $\mathrm{Na}^{+}$is 2.9 for site I, 21.1 for site I', 31.0 for site II, and 29.8 for site III [6]. This distribution of cations in the FAU structure was cleanly explained based on an ordered Si-Al distribution model by Takaishi [7].

Many ways are used to prepare the transition metal containing zeolites: (1) by ion exchange, either from aqueous solution [2-5] or by solid-state reaction [8], (2) by hydrothermal synthesis [9], and (3) by adsorption and decomposition of volatile organometallic compounds [10].

Transition metal ions are often introduced into $\mathrm{NaX}$ zeolites by ion exchange from an aqueous solution. The mechanisms and results of the exchange process are not always simple. Generally, only a part of the original cations, usually sodium ions, can be replaced by transition metal ions. For instance, Bae and Seff demonstrated that this is not the case of three crystal structures where all $\mathrm{Na}^{+}$ions are replaced by $\mathrm{Co}^{2+}$ ions, and $\mathrm{Co}^{2+}$ ions per unit cell of cobalt (II)exchanged $\mathrm{NaX}$ zeolites are at sites I', II, and III of the $\mathrm{NaX}$ zeolites framework structure [11]. 
Cobalt (II) ions, which are often introduced into NaX zeolites by ion exchange, can coordinate more selectively to oxygen atoms compared to filling the shell cations and often have easy access to other oxidation states [11, 12], so their introduction into zeolite leads to new mechanisms for their function as sorbents [13] and catalysts [14]. However, the reversible nature of ion exchange causes once adsorbed nuclides to be reexchanged by other cations $\left(\mathrm{Na}^{+}, \mathrm{Ca}^{2+}\right.$, $\mathrm{Mg}^{2+}$, etc.) in water [12]. Thus, $\mathrm{Co}^{2+}$-exchanged zeolites are often thermally treated to have radioactive cations in unit cells or nonexchangeable crystalline phases [15]. Thermal treatment of zeolite causes dehydration leading to the redistribution of extraframework cations among different types of exchange sites [16]. The dehydration of $\mathrm{NaX}$ zeolites has been shown to induce a migration of $\mathrm{Co}^{2+}$ from site $\mathrm{I}^{\prime}$ to site I, a more restricted and less exchangeable site $[13,17]$.

In this work, we investigate parameters affecting cobalt (II)-exchange process of $\mathrm{NaX}$ zeolites from $\mathrm{Co}\left(\mathrm{NO}_{3}\right)_{2} \cdot 6 \mathrm{H}_{2} \mathrm{O}$ aqueous solution including cobalt (II) concentration, the $\mathrm{pH}$ of the solution, and exchange times. The thermal stability, adsorption properties, and crystalline structure of the thermally treated cobalt (II)-exchanged NaX zeolites were also considered.

\section{Materials and Methods}

2.1. Materials. Ionic exchange was carried out at room temperature by stirring $5 \mathrm{~g}$ of $\mathrm{NaX}$ zeolites (which is the spherical tablets with diameter $\sim 30-35 \mathrm{~mm}$ ) in $250 \mathrm{~mL}$ of aqueous solution containing $\mathrm{Co}\left(\mathrm{NO}_{3}\right)_{2} \cdot 6 \mathrm{H}_{2} \mathrm{O}$. The samples were washed until they were free of nitrate and dried at $120^{\circ} \mathrm{C}$ for $12 \mathrm{~h}$. An atomic absorption spectrometer with a cobalt cathode lamp and air acetylene flame was used for determining $\mathrm{Co}^{2+}$ concentration. Sodium cations containing $\mathrm{NaX}$ zeolites samples exchanged by cobalt cations from $\mathrm{Co}\left(\mathrm{NO}_{3}\right)_{2}$ solutions of varying concentrations, which are $0.05,0.06,0.08,0.10,0.12,0.14,0.16,0.18$, and $0.20 \mathrm{~mol} \mathrm{~L}^{-1}$, were taken and the $\mathrm{pH}$ of solutions was adjusted to $5.00-7.00$ to investigate the effect of cobalt concentration and $\mathrm{pH}$ on the ion exchange from aqueous solution.

The dried samples were thermally treated at different temperatures $\left(400,500,600\right.$, and $\left.700^{\circ} \mathrm{C}\right)$ for $3 \mathrm{~h}$ at a rate of $20^{\circ} \mathrm{C} \mathrm{min}^{-1}$. After thermal treatment, the samples were removed from the furnace and allowed to quench at room temperature. Prior to use, thermally treated samples were stored inside air-tight vials to prevent the absorption of moisture from the atmosphere. Characterization of structure, the size, and morphology of particles were determined by XRD techniques. $\mathrm{N}_{2}$ adsorption isotherm was measured at 77.5 K using a Micromeritics ASAP 2020.

2.2. Exchange Isotherm Models. The Freundlich and Langmuir isotherm models were used to analyze the sorption equilibrium data for Co on $\mathrm{NaX}$ zeolites [18]. The relative coefficients of these models were calculated using linear leastsquares fitting.
The Freundlich isotherm equation $C_{Z}=k_{F} C_{e}^{1 / n}$ can be written in the linear form as follows:

$$
\log C_{Z}=\log k_{F}+\frac{1}{n} \log C_{e},
$$

where $C_{Z}\left(\mathrm{mmol} \mathrm{g}^{-1}\right)$ and $C_{e}\left(\mathrm{mmol} \mathrm{L}^{-1}\right)$ are the equilibrium concentrations of $\mathrm{Co}$ in the zeolite and liquid phases, respectively. $k_{F}$ and $n$ are the Freundlich constants that are related to the sorption capacity and sorption intensity, respectively [19]. The Freundlich constants can be calculated from the slope and intercept of the linear plot of $\log C_{Z}$ versus $\log C_{e}$.

The Langmuir sorption isotherm equation $C_{Z}=$ $Q_{m} K_{L} C_{e} /\left(1+k_{L} C_{e}\right)$ under linearization becomes

$$
\frac{C_{e}}{C_{Z}}=\frac{C_{e}}{Q_{m}}+\frac{1}{Q_{m} k_{L}},
$$

where $Q_{m}$ and $k_{L}$ are the Langmuir constants which are related to sorption capacity and energy of sorption, respectively, and can be calculated from the intercept and slope of the linear plot of $C_{e} / C_{Z}$ versus $C_{e}$.

2.3. Kinetic Models. The pseudo-second-order kinetic model was used to analyze the sorption kinetic data for cobalt on various adsorbents [20]. The pseudo-second-order equation was written as follows:

$$
\frac{d q_{t}}{d t}=k_{2}\left(q_{e}-q_{t}\right)^{2}
$$

where $k_{2}\left(\mathrm{~g} \mathrm{mg}^{-1} \mathrm{~min}^{-1}\right)$ is the rate constant and $q_{t}$, $q_{e}\left(\mathrm{mg} \mathrm{g}^{-1}\right)$ are the amount of sorption at time $t$ (min) and at equilibrium.

Integration of (3) and application of the above conditions give

$$
\frac{1}{q_{e}-q_{t}}=\frac{1}{q_{e}}+k_{2} t
$$

After rearranging (4) into a linear form, give

$$
\frac{t}{q_{t}}=\frac{1}{k_{2} q_{e}^{2}}+\frac{1}{q_{e}} t
$$

$k_{2}$ and $q_{e}$ can be obtained from the intercept and slope of the plot $t / q_{t}$ versus $t$.

2.4. Analysis of Surface Properties. X-ray powder diffraction studies at ambient temperature were carried out using a PANalytical X'pert PRO system in the $2 \theta$ range of 5 to $60^{\circ}$ using $\mathrm{Cu} \mathrm{K} \alpha_{1}(\lambda=1.540598 \AA)$.

Scanning electron microscopy (SEM) imaging was studied with a JOEL microscope (model JSM 6330 TF).

The adsorption-desorption isotherms were collected in an ASAP 2020 instrument (Micromeritics) at $77.5 \mathrm{~K}$. The obtained data were analyzed using the $t$-plot, BrunauerEmmett-Teller (BET; specific surface area), and BarrettJoyner-Halenda (BJH; pore diameter, pore distribution, and micro- and mesopore volume) models. 


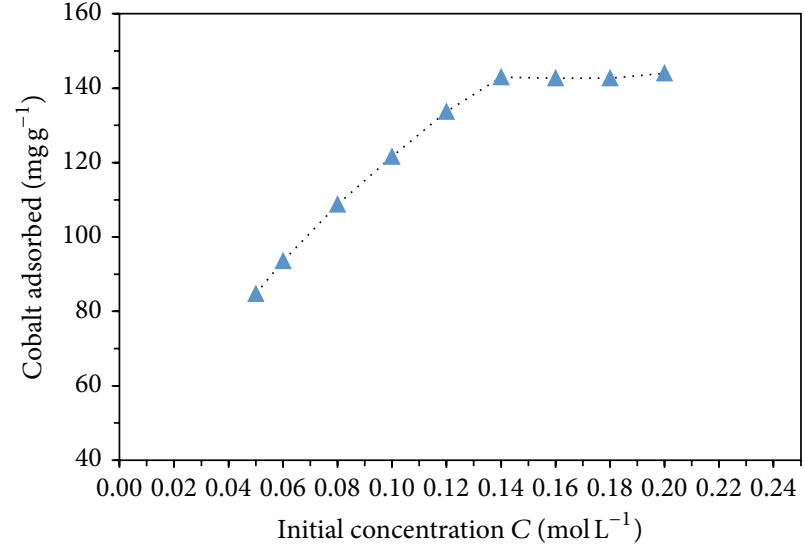

(a)

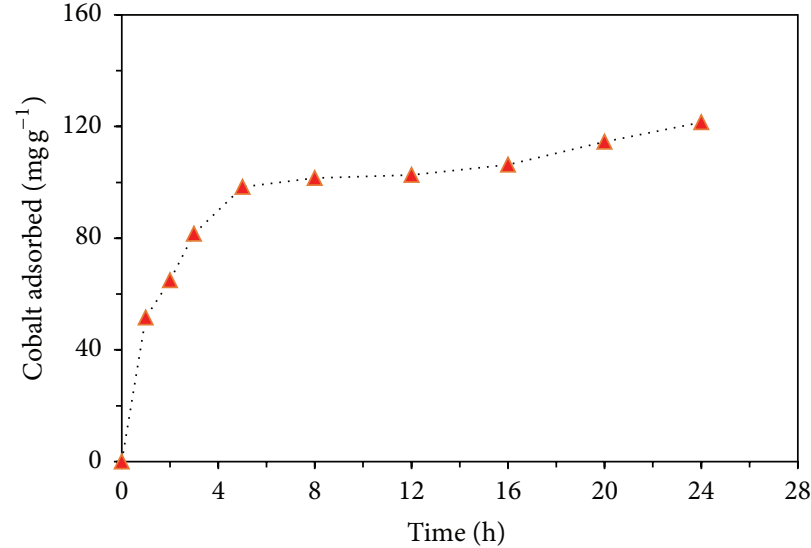

(b)

Figure 1: Effect of the initial concentration (a) and contact time (b) in the $\mathrm{Co}^{2+}$ exchange at room temperature.
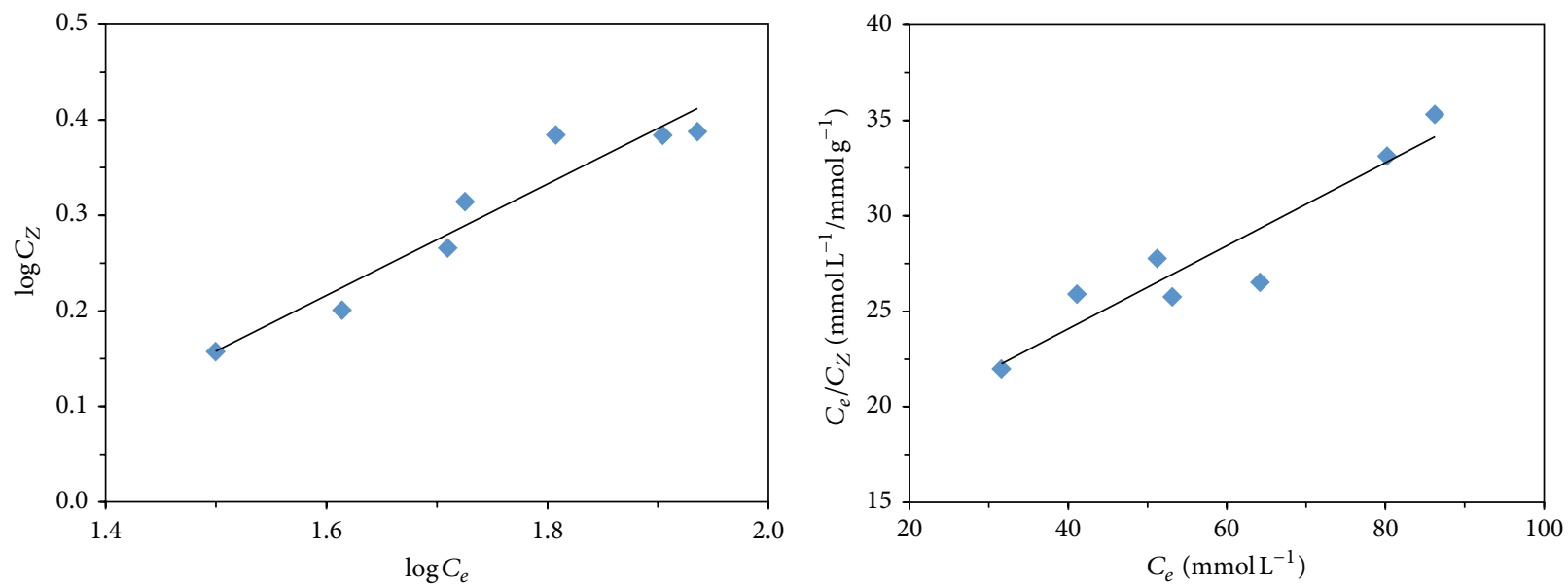

FIGURE 2: Freundlich sorption and Langmuir sorption isotherm of cobalt (II) at $\mathrm{pH}=6.05$.

\section{Results and Discussion}

3.1. Effect of $p H$, Initial Concentration, and Stirring Time on Exchange. Cobalt (II)-exchange process is taken at various values of the $\mathrm{pH}$ of the solution to investigate the effect of the $\mathrm{pH}$. The investigated results show that $\mathrm{Co}^{2+}$ exchange is dependent on the $\mathrm{pH}$ of the solution. The Co adsorbed is low at low $\mathrm{pH}$ and it increases with increasing $\mathrm{pH}$. In the $\mathrm{NaX}$ zeolites framework, $\mathrm{Na}$ ions were attracted to sites I, I', II, and III' by Coulomb's force (caused by surrounding Al atoms) and short range interaction with the oxygen atoms of the framework $[6,7]$. However, the Si-O-Al bonds can easily be attracted by the $\mathrm{H}^{+}$affecting the zeolite structure, which in turn results in the decreased presence of $\mathrm{Na}$ ions in framework [21]. Thus, the loss of $\mathrm{Co}^{2+}$-exchange capacity of $\mathrm{NaX}$ zeolite at lower $\mathrm{pH}$ can therefore be ascribed to the collapse in the structure of the zeolite. The NaX zeolites structure is very stable at higher $\mathrm{pH}$. This is why the $\mathrm{Co}^{2+}$ exchange capacity is higher. When the $\mathrm{pH}$ of solution is higher than 6.5, the cobalt amount exchanged is reduced due to the lessening of $\mathrm{Co}^{2+}$ concentration in aqueous solution, coinciding with the condensation of cobalt hydroxide.
It was known that $\mathrm{Co}(\mathrm{OH})_{2}$ condensation begins to occur in the $\mathrm{Co}^{2+}$ solution with a concentration of $0.1\left(\mathrm{~mol} \mathrm{~L}^{-1}\right)$ at $\mathrm{pH}$ $=6.05$.

Data relating to the effect of the initial concentration of solution and the contact time in the cobalt exchange at room temperature is shown in Figure 1. The figures indicate that the cobalt adsorbed increased with increasing the initial concentration of solution up to $0.14 \mathrm{~mol} \mathrm{~L}^{-1}$ and then it was nearly unchanged (Figure 1(a)). In addition, the cobalt adsorbed was rapidly increased at the first five hours, and then it was slowly increased with increasing the stirring time (Figure 1(b)).

3.2. Exchange Isotherms. The sorption isotherm of cobalt on $\mathrm{NaX}$ zeolites at room temperature is shown in Figure 2. The shape of the isotherm shows that the ion-exchange process occurs. The exchange data were measured in terms of Freundlich and Langmuir isotherm models. The fitted constants for the Freundlich and Langmuir models along with regression coefficients are listed in Table 1 . The results and graphical isotherm in Figure 2 show that the fitting is 
TABLE 1: Freundlich, Langmuir, and pseudo-second-order model constants.

\begin{tabular}{lcr}
\hline Isotherm model & \multicolumn{2}{c}{ Constants } \\
\hline Freundlich $\left(R^{2}=0.92\right)$ & $k_{F}=0.2$ & $n=1.72$ \\
\hline Langmuir $\left(R^{2}=0.89\right)$ & $k_{L}=1.4 \times 10^{-2}$ & $Q_{m}=4.6$ \\
\hline Pseudo-second-order $\left(R^{2}=0.994\right)$ & $k_{2}=7.2 \times 10^{-5}\left(\mathrm{~g} \mathrm{mg}^{-1} \mathrm{~min}^{-1}\right)$ & $q_{e}=125\left(\mathrm{mgg} \mathrm{g}^{-1}\right)$ \\
\hline
\end{tabular}

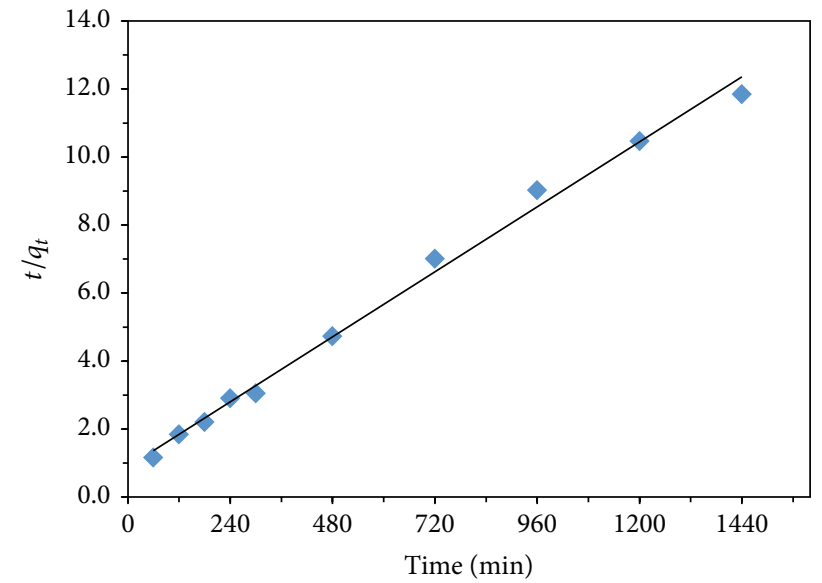

FIGURE 3: Pseudo-second-order sorption kinetic model of cobalt (II) on $\mathrm{NaX}$ zeolite.

better under the Freundlich model $\left(R^{2}=0.92\right)$ than with the Langmuir model $\left(R^{2}=0.89\right)$.

3.3. Exchange Kinetics. This study performed the following ion exchange:

$$
\mathrm{Co}_{(\mathrm{aq})}^{2+}+\mathrm{Na}-\mathrm{X}_{(\mathrm{zeo})} \stackrel{K}{\longleftrightarrow} z \mathrm{Na}_{(\mathrm{aq})}^{+}+\mathrm{Co}-\mathrm{X}_{(\mathrm{zeo})}
$$

The kinetics of ion exchange describing the rate of the uptake of cobalt is one of the important characteristics defining the capacity of ion exchange. The experimental exchange kinetic data were fitted to pseudo-second-order rates, as shown in (5). The observation of linearity from Figure 3 indicates that the exchange kinetic data are well represented by the pseudo-second-order model for cobalt (with regression coefficient, $R^{2}=0.994$ ) for $\mathrm{NaX}$ zeolites. The rate of $\mathrm{Co}^{2+}$ exchange $\left(k_{2}\right)$ and the equilibrated amount of cobalt were $7.2 \times 10^{-5}\left(\mathrm{~g} \mathrm{mg}^{-1} \mathrm{~min}^{-1}\right)$ and $125\left(\mathrm{mg} \mathrm{g}^{-1}\right)$, respectively (the initial concentration of cobalt (II) solution is $\left.0.1 \mathrm{~mol} \mathrm{~L}^{-1}\right)$. This cobalt (II)-exchanged $\mathrm{NaX}$ zeolite was labeled as $0.1-\mathrm{NaCoX}$, where $0.1 \mathrm{~mol} \mathrm{~L}^{-1}$ is the concentration of the cobalt (II) solution.

3.4. X-Ray Diffraction and SEM Analysis. The X-ray diffraction patterns of $\mathrm{NaX}$ and the thermal effect on $\mathrm{Co}^{2+}$ exchanged $\mathrm{NaX}$ zeolites were shown in Figure 4. It can be seen that the faujasite framework of $\mathrm{NaX}$ zeolite is retained during the cobalt exchange process. However, the rapid decrease in crystallinity was due to the presence of cobalt ions in the $\mathrm{NaX}$ zeolite framework, leading to decreased unit cell dimension.

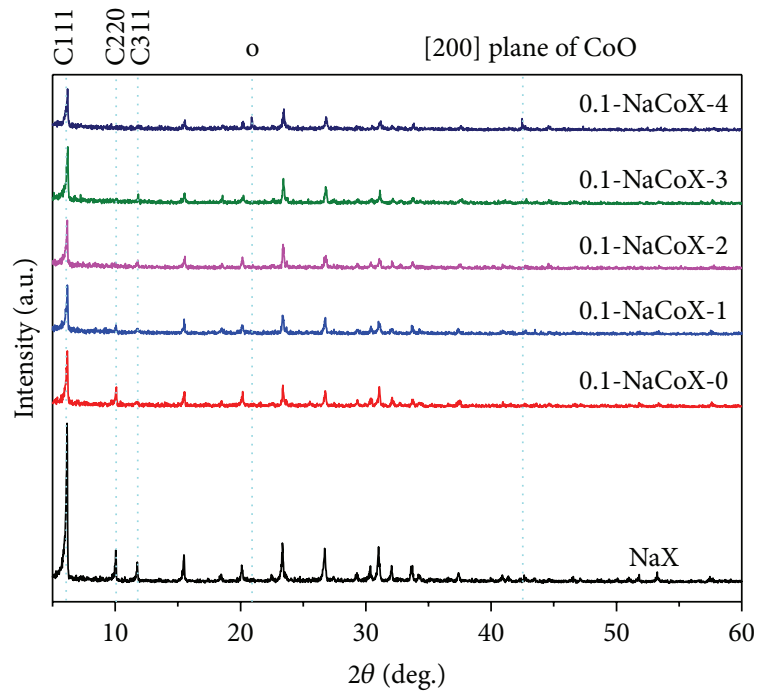

Figure 4: X-ray powder diffraction patterns of $\mathrm{NaX}$ and $0.1-\mathrm{NaCoX}$ thermally treated zeolites: thermally untreated sample $\mathrm{NaCoX}-0$ and the samples treated at $400^{\circ} \mathrm{C}$ for $3 \mathrm{~h}(0.1-\mathrm{NaCoX}-1), 500^{\circ} \mathrm{C}$ for $3 \mathrm{~h}$ (0.1-NaCoX-2), $600^{\circ} \mathrm{C}$ for $3 \mathrm{~h}(0.1-\mathrm{NaCoX}-3)$, and $700^{\circ} \mathrm{C}$ for $3 \mathrm{~h}(0.1-$ $\mathrm{NaCoX}-4)$.

Figure 4 showed that the framework structure was retained up to $600^{\circ} \mathrm{C}$, but it was damaged at $T>700^{\circ} \mathrm{C}$ because the amorphization occurred during the thermal treatment. Hence, the (220) and (311) peaks at $2 \theta=10.03$ and 11.7 disappeared in X-ray diffraction pattern of $\mathrm{NaCoX}$ 4. Moreover, the position of the (111) peak at $2 \theta=6.14(d=$ $14.45 \AA$ ) shifted to lower $d$ values under thermal treatment. In this study, the unit cell parameter was calculated for the cubic symmetry as $24.835 \AA$ for the untreated sample, $24.827 \AA$ for the sample treated at $400^{\circ} \mathrm{C}$ for $3 \mathrm{~h}$, and $24.703 \AA$ for the sample treated at $600^{\circ} \mathrm{C}$ for $3 \mathrm{~h}$. This finding agrees with the studies of Jeong et al. [13] and the unit cell parameters were decreased due to a dehydration.

XRD patterns of 0.1-NaCoX (Figure 4) were compared to the studied results of Jonynaite et al. [22] and of Jeong et al. [13] to reveal the presence of the peaks of cobalt oxides and of carnegeite as a secondary phase. For instance, the peak is at $2 \theta=42.4$ (degrees) which corresponds to the [200] plane of $\mathrm{CoO}$ (ICDD \#45-1004) and at $2 \theta=21.1$ (degrees) for the carnegeite.

The SEM images of the NaX zeolite and thermally treated cobalt (II)-exchange zeolite samples were shown in Figure 5. It can be seen that there is no notable change in morphology in $\mathrm{NaX}$ zeolite under cobalt (II)-exchange process (Figures $5(\mathrm{a})-5(\mathrm{c}))$. The nearly spherical shape crystallite sizes are approximately $1-3 \mathrm{~m} \mu$ for most of the samples. Thus, the 


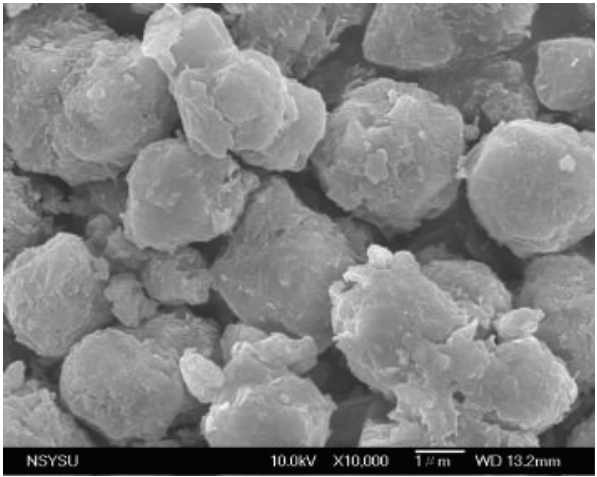

(a)

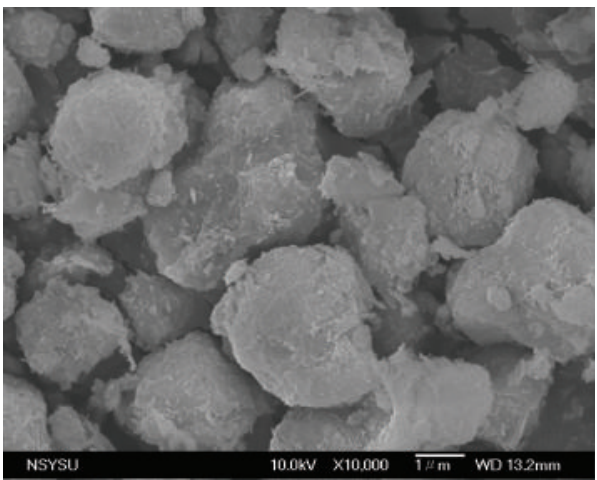

(c)

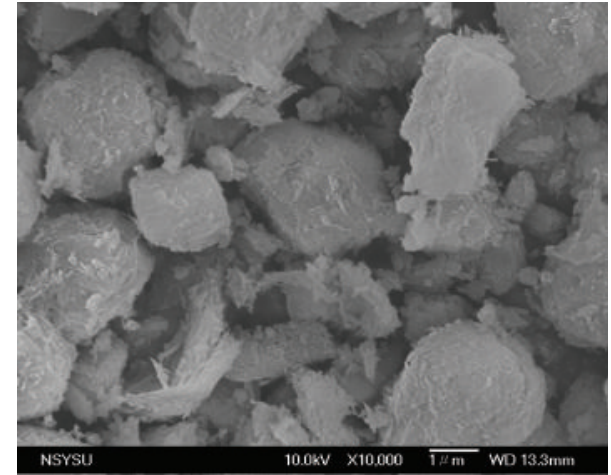

(b)

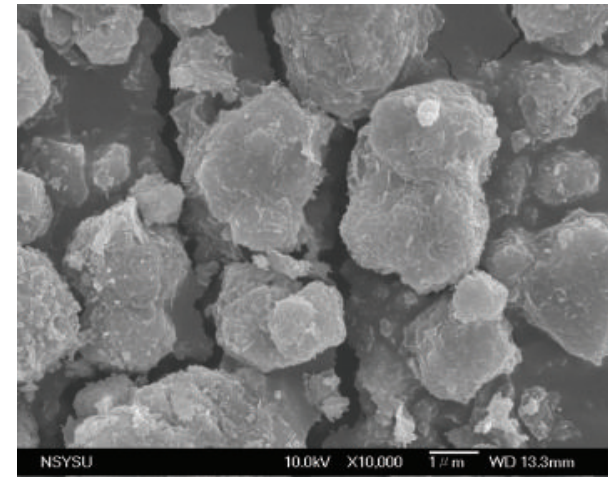

(d)

Figure 5: SEM images of $\mathrm{NaX}$ and $0.1-\mathrm{NaCoX}$ thermally treated zeolites: $\mathrm{NaX}$ sample (a) and the samples treated at $400^{\circ} \mathrm{C}$ for $3 \mathrm{~h}(\mathrm{~b}), 600^{\circ} \mathrm{C}$ for $3 \mathrm{~h}(\mathrm{c})$, and $700^{\circ} \mathrm{C}$ for $3 \mathrm{~h}(\mathrm{~d})$.

TABLE 2: The surface area and pore size of NaX zeolites and $\mathrm{Co}^{2+}$-exchanged zeolites: NaX zeolite, untreated sample (0.1-NaCoX-0), and the samples treated at $400^{\circ} \mathrm{C}$ for $3 \mathrm{~h}(0.1-\mathrm{NaCoX}-1), 500^{\circ} \mathrm{C}$ for $3 \mathrm{~h}(0.1-\mathrm{NaCoX}-2), 600^{\circ} \mathrm{C}$ for $3 \mathrm{~h}(0.1-\mathrm{NaCoX}-3)$, and $700^{\circ} \mathrm{C}$ for $3 \mathrm{~h}(0.1-\mathrm{NaCoX}-4)$.

\begin{tabular}{|c|c|c|c|c|c|}
\hline \multirow[b]{2}{*}{ Adsorbents } & \multirow{2}{*}{$\begin{array}{c}\text { BET surface area, } \\
S_{\mathrm{BET}} / \mathrm{m}^{2} \mathrm{~g}^{-1}\end{array}$} & \multicolumn{2}{|c|}{$t$-plot } & \multirow{2}{*}{ BJH pore diameter/Å } & \multirow{2}{*}{$\begin{array}{c}\text { BJH pore volume, } \\
V_{\text {meso }} / \mathrm{cm}^{3} \mathrm{~g}^{-1}\end{array}$} \\
\hline & & $\begin{array}{l}\text { Micropore surface area, } \\
S_{\text {micro }} / \mathrm{m}^{2} \mathrm{~g}^{-1}\end{array}$ & $\begin{array}{l}\text { External surface area, } \\
\qquad S_{\text {ext }} / \mathrm{m}^{2} \mathrm{~g}^{-1}\end{array}$ & & \\
\hline $\mathrm{NaX}$ & 388 & 344 & 45 & 151.5 & 0.132 \\
\hline $0.1-\mathrm{NaCoX}-0$ & 413 & 340 & 73 & 30.4 & 0.144 \\
\hline 0.1-NaCoX-1 & 395 & 316 & 79 & 42.7 & 0.172 \\
\hline 0.1-NaCoX-2 & 390 & 304 & 85 & 48.4 & 0.188 \\
\hline $0.1-\mathrm{NaCoX}-3$ & 382 & 302 & 80 & 97.0 & 0.176 \\
\hline 0.1-NaCoX-4 & 341 & 282 & 58 & 92.0 & 0.177 \\
\hline
\end{tabular}

cobalt (II) exchange does not cause the significant collapse of the crystalline structure of the $\mathrm{NaX}$ zeolite. This result is consistent with the result analyzed by XRD diffraction. On the other hand, the shape and surface of the particles were retained up to $600^{\circ} \mathrm{C}$ and then they were distorted at higher temperature as shown in Figure 5(d).

3.5. Nitrogen Adsorption. Figure 6 presents the nitrogen adsorption/desorption isotherms for each of $\mathrm{NaX}$ and 0.1$\mathrm{NaCoX}$ zeolites treated at various temperatures. The curves show that the micropore filling is observed at a relatively low pressure because of the narrow pore width and the high adsorption potential; therefore, the isotherms are type I isotherm for microporous materials (Figure 6(a)). However, a plateau was not achieved at $p / p_{o} \geq 0.8$, obviously indicating expansion of the pore; that is, mesopore adsorption contributed to the adsorption process. This is a characteristic of type II isotherm. According to these results, the adsorption isotherms are mixed types I/II. The microporous adsorption contribution in 0.1-NaCoX zeolites is less than that in $\mathrm{NaX}$ zeolites because the Co exchange into a zeolite makes the zeolite surface more porous and rough. This was revealed from an increase in the slope of the region in the middle of the 


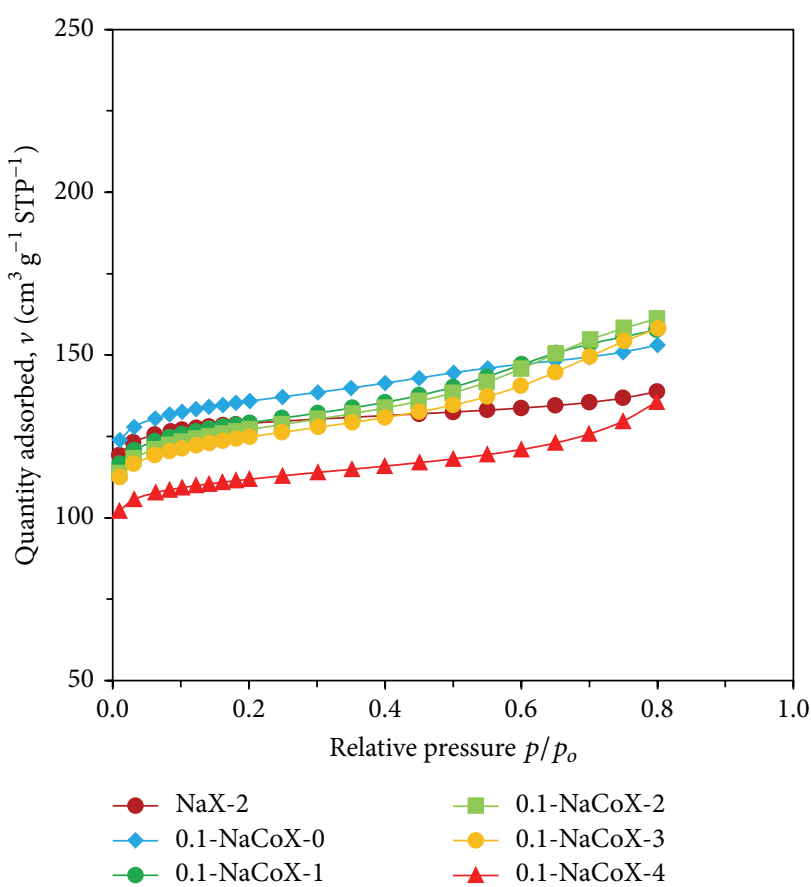

(a)

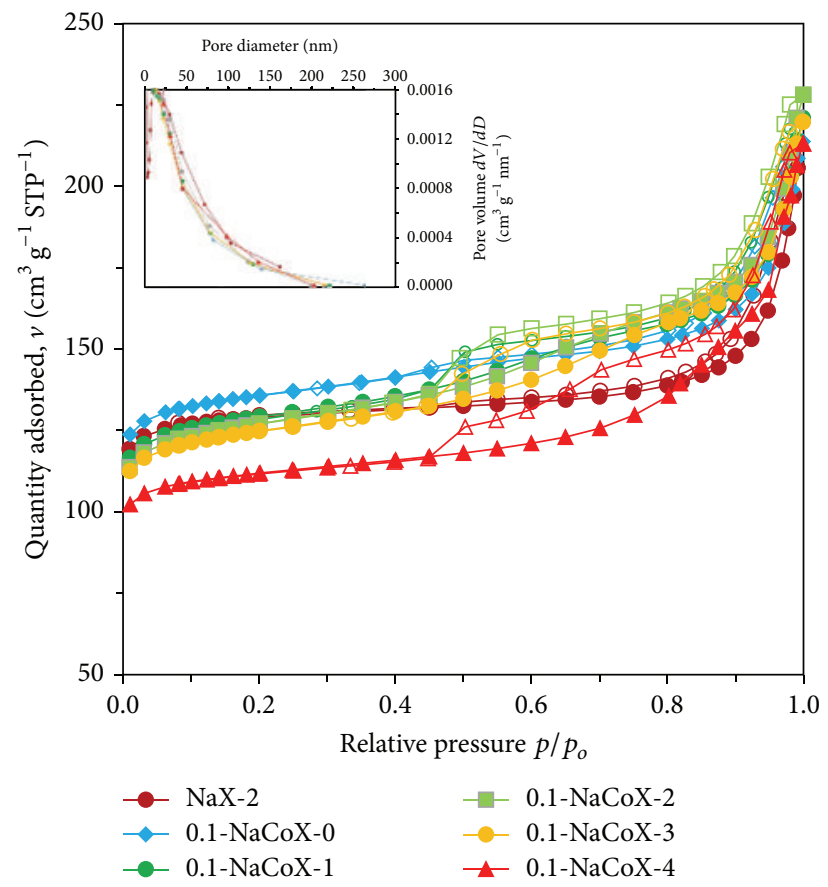

(b)

Figure 6: $t$-plot isotherms (a) and $\mathrm{N}_{2}$ adsorption (solid symbols)/desorption (open symbols) isotherms (b) of $\mathrm{NaX}$ and thermally treated $0.1-\mathrm{NaCoX}$ zeolites.

adsorption isotherm curves of the $\mathrm{NaX}$ zeolites after cobalt (II) exchanges. In addition, the adsorption isotherms on the $0.1-\mathrm{NaCoX}$ samples suggest an optimal range of treatment temperature to be 500 to $600^{\circ} \mathrm{C} . V_{\text {micro }}, S_{\mathrm{BET}}, S_{\text {ext }}$, and $S_{\text {micr }}$ of the thermally treated $0.1-\mathrm{NaCoX}$ samples are also derived from the $t$-plot and are listed in Table 2. It can be seen that the specific surface areas of the $0.1-\mathrm{NaCoX}$ samples are greater than those of the $\mathrm{NaX}$ zeolites because the $0.1-\mathrm{NaCoX}$ surface becomes more porous and rough after Co exchange occurred. This is clearly indicated in the comparison of the external surface area of samples. In the thermally treated $0.1-\mathrm{NaCoX}$ zeolites, the specific surface areas and micropore surface areas decrease with increasing temperature due to compression of materials, caused by treatment at high temperature. However, the external surface areas slightly increase with increasing temperature up to $600^{\circ} \mathrm{C}$. The causes of this phenomenon will be discussed below.

Nitrogen adsorption/desorption at $77.5 \mathrm{~K}$ on $\mathrm{NaX}$ and $0.1-$ $\mathrm{NaCoX}$ are shown in Figure 6(b). The figure reveals that the hysteresis loop for nitrogen adsorption on the samples closed at the relative pressure of $4.0-4.5$, which indicates the presence of small mesopores. Here, the hysteresis stays open longer but for the tensile strength failure of the nitrogen meniscus occurs; that is, hysteresis (type of H3) shows capillary condensation in mesopores. The first steep indicates the approximate location of monolayer formation. The low slope region in the middle of the isotherm shows the first few multilayers. The realistic pore size can be obtained from analysis of the adsorption branch and these values are listed in Table 2. Pore diameter increases with increasing temperature because of the texture collapse of zeolite under thermal treatment leading to an increase of the external surface area and mesopore volume. The pore size of $\mathrm{NaX}$ zeolite strongly decreases after cobalt (II) exchange occurred. It was the difference of diameter of hydrated cations that caused this phenomenon. The thermal treatment of $0.1-\mathrm{NaCoX}$ zeolite at $500^{\circ} \mathrm{C}$ leads to the highest value in the external surface area $\left(S_{\text {ext }}=85 \mathrm{~m}^{2} \mathrm{~g}^{-1}\right)$ and mesopore volume $\left(V_{\text {meso }}=\right.$ $\left.0.188 \mathrm{~cm}^{3} \mathrm{~g}^{-1}\right)$.

\section{Conclusions}

The $\mathrm{Co}^{2+}$-exchanged $\mathrm{NaX}$ zeolites were prepared by the ionexchange process from $\mathrm{Co}\left(\mathrm{NO}_{3}\right)_{2}$ solution. This experimental data followed both the Freundlich and Langmuir isotherm models well with high regression coefficients as $R^{2}=0.92$ and 0.89 , respectively. Moreover, the pseudo-second-order model could be used to apply the exchange kinetic data of the exchange process (with regression coefficient $R^{2}=0.994$ ). The rate of $\mathrm{Co}^{2+}$ exchange $\left(k_{2}\right)$ and the equilibrated amount of cobalt were $7.2 \times 10^{-5}\left(\mathrm{~g} \mathrm{mg}^{-1} \mathrm{~min}^{-1}\right)$ and $125\left(\mathrm{mg} \mathrm{g}^{-1}\right)$, respectively (the initial concentration of cobalt (II) solution of $0.1 \mathrm{~mol} \mathrm{~L}^{-1}$ ). According to investigated results, the $\mathrm{Co}^{2+}$ exchange process on $\mathrm{NaX}$ zeolite was dependent on the $\mathrm{pH}$ of the metal solution, the initial concentration of metal ions, and contact time.

The faujasite framework of $\mathrm{NaX}$ zeolite was retained during the cobalt exchange process under the thermal treatment up to $600^{\circ} \mathrm{C}$. The position and intensity of the reflection 
peaks of $0.1-\mathrm{NaCoX}$ were changed due to hydration, leading to surface structure change during thermal treatment.

The nitrogen adsorption isotherms on $\mathrm{NaX}$ and 0.1 $\mathrm{NaCoX}$ zeolites at $77.5 \mathrm{~K}$ were mixed types $\mathrm{I} / \mathrm{II}$ isotherms and $\mathrm{H} 3$ type hysteresis. Both the micropore and mesopore adsorptions contributed to the adsorption process. Hence, a more realistic pore size can be obtained from analysis of an adsorption branch. The surface areas of $0.1-\mathrm{NaCoX}$ samples were greater than those of $\mathrm{NaX}$, and pore diameter and external surface area increased with increasing treatment temperature up to $600^{\circ} \mathrm{C}$. Accordingly, the optimal temperature range is 500 to $600^{\circ} \mathrm{C}$ for thermal treatment. This is consistent with the results of XRD analysis.

\section{Competing Interests}

The authors declare that they have no competing interests.

\section{Acknowledgments}

The authors wish to thank the Ministry of Science and Technology of Taiwan, MOST (103-2221-E-151-062), for their financial support of this work.

\section{References}

[1] R. T. Yang, Adsorbents: Fundamentals and Applications, WileyInterscience, New York, NY, USA, 2003.

[2] S. Bendenia, K. Marouf-Khelifa, I. Batonneau-Gener, Z. Derriche, and A. Khelifa, "Adsorptive properties of $\mathrm{X}$ zeolites modified by transition metal cation exchange," Adsorption, vol. 17, no. 2, pp. 361-370, 2011.

[3] A. Khelifa, Z. Derriche, and A. Bengueddach, "Adsorption of propene on $\mathrm{NaX}$ zeolite exchanged with $\mathrm{Zn}^{2+}$ and $\mathrm{Cu}^{2+}$," Applied Catalysis A: General, vol. 178, no. 1, pp. 61-68, 1999.

[4] H. Hammoudi, S. Bendenia, K. Marouf-Khelifa, R. Marouf, J. Schott, and A. Khelifa, "Effect of the binary and ternary exchanges on crystallinity and textural properties of X zeolites," Microporous and Mesoporous Materials, vol. 113, no. 1-3, pp. 343351, 2008.

[5] J. Sebastian, S. A. Peter, and R. V. Jasra, "Adsorption of nitrogen, oxygen, and argon in cobalt (II) - exchanged zeolite X," Langmuir, vol. 21, no. 24, pp. 11220-11225, 2005.

[6] D. H. Olson, "The crystal structure of dehydrated NaX," Zeolites, vol. 15, no. 5, pp. 439-443, 1995.

[7] T. Takaishi, "Ordered distribution of $\mathrm{Na}$ ions in dehydrated $\mathrm{NaX}$ zeolite," Zeolites, vol. 17, no. 4, pp. 389-392, 1996.

[8] R. M. Haniffa and K. Seff, "Partial structures of solid-state copper(II)-exchanged zeolite $\mathrm{Y}$ and its $\mathrm{D}_{2} \mathrm{O}$ sorption complex by pulsed-neutron diffraction," Microporous and Mesoporous Materials, vol. 25, no. 1-3, pp. 137-149, 1998.

[9] P. Feng, X. Bu, and G. D. Stucky, "Hydrothermal syntheses and structural characterization of zeolite analogue compounds based on cobalt phosphate," Nature, vol. 388, no. 6644, pp. 735741, 1997.

[10] G. C. Shen, T. Shido, and M. Ichikawa, "Cobalt clusters in NaY zeolite cages: synthesis and characterization," The Journal of Physical Chemistry, vol. 100, no. 42, pp. 16947-16956, 1996.
[11] D. Bae and K. Seff, "Structures of cobalt (II)—exchanged zeolite X," Microporous and Mesoporous Materials, vol. 33, no. 1-3, pp. 265-280, 1999.

[12] A. Dryer, An Introduction to Zeolite Molecular Sieves, John Wiley \& Sons, Chichester, UK, 1988.

[13] H. Y. Jeong, D.-C. Koh, K.-S. Lee, and H. H. Lee, "Characterization of thermally treated $\mathrm{Co}^{2+}$-exchanged zeolite X," Applied Catalysis B: Environmental, vol. 127, pp. 68-76, 2012.

[14] J. Sebastian, K. M. Jinka, and R. V. Jasra, "Effect of alkali and alkaline earth metal ions on the catalytic epoxidation of styrene with molecular oxygen using cobalt(II)-exchanged zeolite X," Journal of Catalysis, vol. 244, no. 2, pp. 208-218, 2006.

[15] R. Rodríguez-Trejo, P. Bosch, and S. Bulbulian, "Combustion treatment of $\mathrm{Co}^{2+}$ and $\mathrm{Cs}^{+}$exchanged zeolites," Journal of Nuclear Materials, vol. 354, no. 1-3, pp. 110-122, 2006.

[16] T. Frising and P. Leflaive, "Extraframework cation distributions in X and Y faujasite zeolites: a review," Microporous and Mesoporous Materials, vol. 114, no. 1-3, pp. 27-63, 2008.

[17] E. Borissenko, F. Porcher, A. Bouché, C. Lecomte, and M. Souhassou, "Single crystal structure of fully dehydrated partially $\mathrm{Co}^{2+}$-exchanged zeolite $\mathrm{X}$ : comparison with partially dehydrated partially $\mathrm{Co}^{2+}$-exchanged zeolites X," Microporous and Mesoporous Materials, vol. 114, no. 1-3, pp. 155-165, 2008.

[18] S. Glasstone, Text Book of Physical Chemistry, Macmillan, Chennai, India, 2nd edition, 1981.

[19] M. Prasad, S. Saxena, S. S. Amritphale, and N. Chandra, "Kinetics and isotherms for aqueous lead adsorption by natural minerals," Industrial \& Engineering Chemistry Research, vol. 39, no. 8, pp. 3034-3037, 2000.

[20] Y. S. Ho and G. McKay, "Pseudo-second order model for sorption processes," Process Biochemistry, vol. 34, no. 5, pp. 451-465, 1999.

[21] R. Xu, W. Pang, J. Yu, Q. Huo, and J. Chen, Chemistry of Zeolites and Related Porous Materials: Synthesis and Structure, John Wiley \& Sons, Singapore, 2007.

[22] D. Jonynaite, J. Senvaitiene, J. Kiuberis, A. Kareiva, R. Juškenas, and R. Ramanauskas, "XRD characterization of cobalt-based historical pigments and glazes," Chemija, vol. 20, no. 1, pp. 10-18, 2009. 

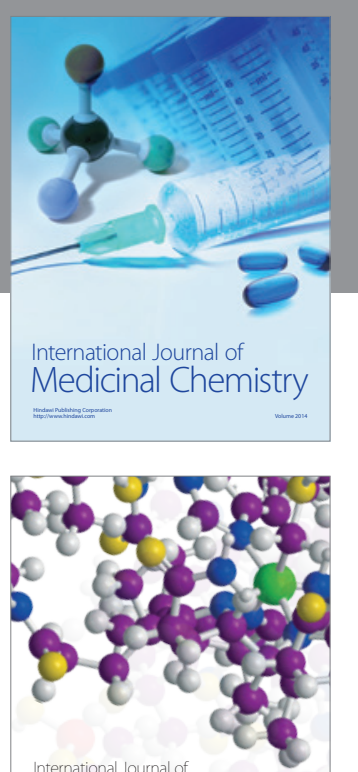

Carbohydrate Chemistry

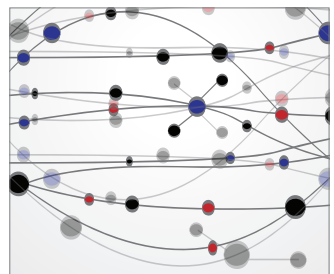

The Scientific World Journal
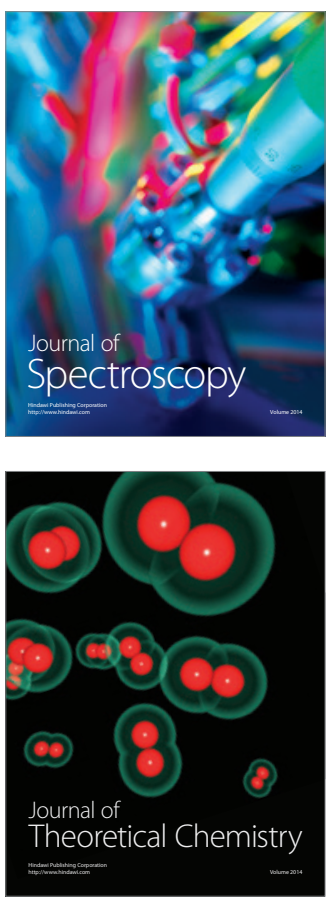
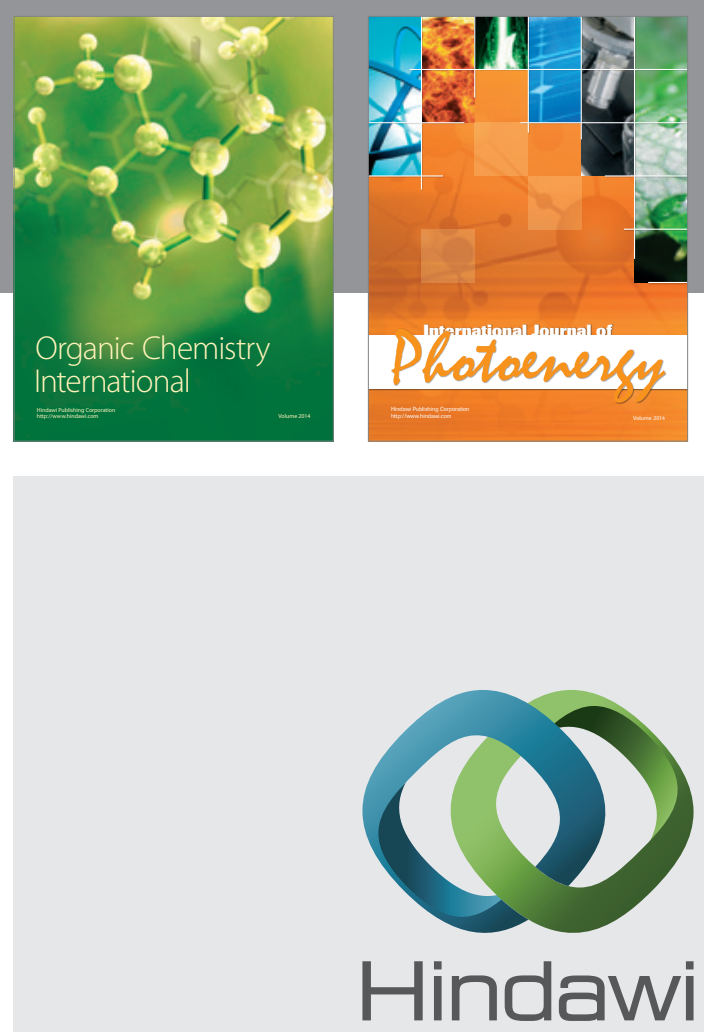

Submit your manuscripts at

http://www.hindawi.com

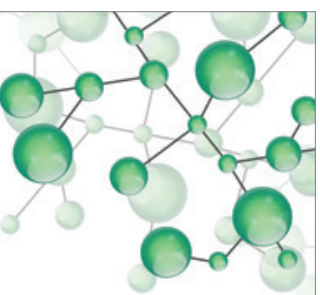

International Journal of

Inorganic Chemistry

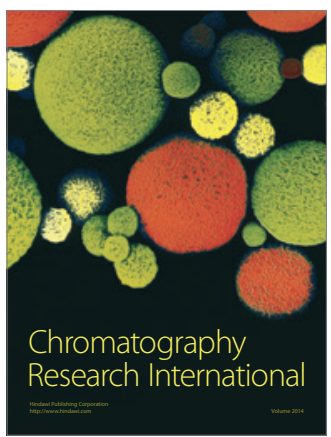

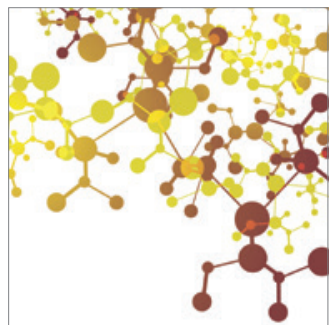

Applied Chemistry
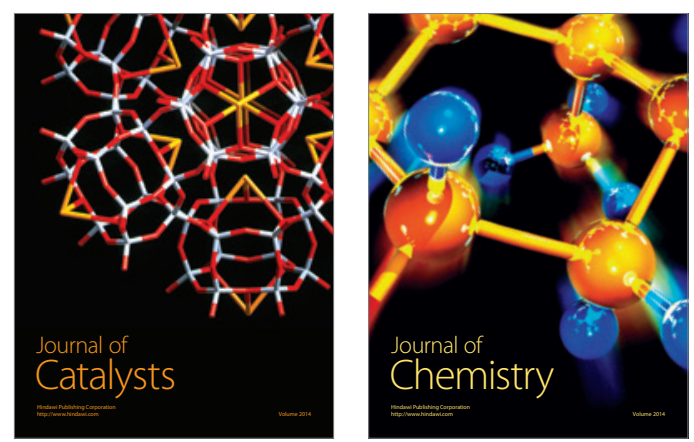
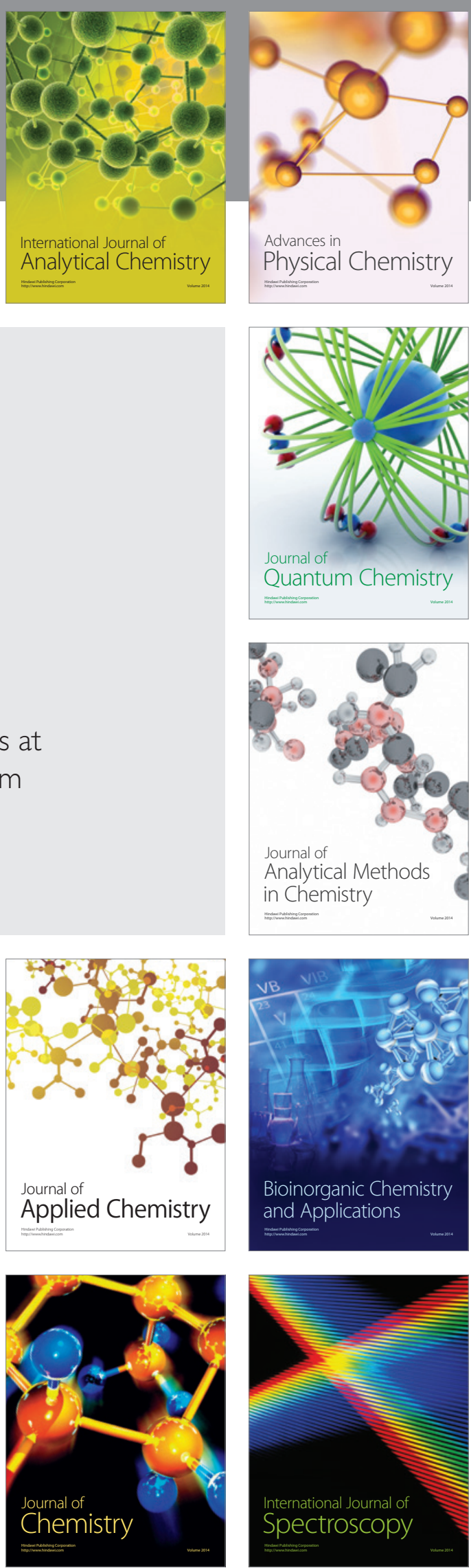